\title{
SYNTHESIS N-PHENYLAMINEDITHIOCARBAMATE AS CHELATING AGENT IN SOLVENT EXTRACTION
}

\author{
Soja Siti Fatimah ${ }^{1,2}$, Vera Musfiroh ${ }^{1}$, Zackiyah ${ }^{1}$, Husein H. Bahti ${ }^{2}$, Iwan Hastiawan ${ }^{2}$, Anna \\ Permanasari $^{1}$ \\ ${ }^{1}$ Department of Education Chemistry, FPMIPA, UPI Jl. Dr. Setiabudhi No. 229 Bandung 40154, Indonesia \\ ${ }^{2}$ Department Chemistry, FMIPA Unpad ,Jl. Raya Bandung-Sumedang Km 21 Jatinangor \\ *Alamat korespondensi: ssfatimah@gmail.com
}

\begin{abstract}
Dithiocarbamate derivatives is a versatile ligand that contain two atoms of sulfur as a strong electron donor. It combines with metals. N-phenylaminedithiocarbamate has synthesized and applied in solvent exctration. Synthesis carried out with addition carbon disulphide to $N$-phenylamine and concentrated pottasium hydroxyde in metanol. The result was characterized by spectroscopy ${ }^{1} H-N M R,{ }^{13} C-N M R$, FTIR, Elemental Analysis, that showed molecular structure was significant. Applied N-Phenylaminedithiocarbamate in solvent extraction showed precent of result $\mathrm{Cu}(\mathrm{II}), \mathrm{Co}(\mathrm{II}), \mathrm{Cr}(\mathrm{III})$ and $\mathrm{Ni}(\mathrm{II})$ were $90.45 \%-99.99 \%$ at $\mathrm{pH}$ 4-9.
\end{abstract}

Keywords: $N$-phenylaminedithiocarbamate, chelating agents. solvent extraction

\section{INTRODUCTION}

Recently, major advances on the synthesis of derivative chemicals from dithiocarbamate have been made. This material is attractive because of its potential applications in wide range of fields, such as a vulcanization additive in rubber industry, an inhibitor for enzimatic reaction (Shi et al, 2013; Manay et al., 2004; Manay et al., 2006), a photoelectronic, an adsorbent, a catalyst (Onwudiwe et al., 2013; Cao et al., 2013) an agent for pesticide, and a chelating agent (Shi et al, 2013; Manay et al., 2004; Manay et al., 2006; Onwudiwe et al., 2013; Cao et al., 2013).

For the chelating agent, dithiocarbamate derivative has been of greatly interest. Many papers reported that this derivative component is effective to be applied and composed with many metal components. Dilli and Hutchins reported the use of dialkyldithiocarbamate, which was effective to be combined with $\mathrm{Zn}(\mathrm{II})$, As(III), Fe(III), Cd(II), Ni(II), $\mathrm{Cu}(\mathrm{II}), \mathrm{Hg}(\mathrm{II}), \quad \mathrm{Co}(\mathrm{II})$ and $\mathrm{Cr}(\mathrm{III})$ in liquid chromatography.

Although current developed methods are effective to produce chelate material, information on how to synthesize dithiocarbamate derivative and their chelate ability is still lacking. Most of the papers discussed about how to synthesize this type of chemical only but with no detailed analysis and characterization on ligands and complex structure. These limitations creates problem for practical applications (i.e. scaling up process). Further, derivatives of straight chan alkyl dithiocarbamate is more frequently used than cyclic., In fact, although there is structure that preferred for leading more active and nucleophilic. In addition, current reports did not incorporate with some information in the realistic applications, such as solvent extraction.

The purpose of this study was to synthesize $\mathrm{N}$ phenylaminedithiocarbamate as a chelathing agent and applied in solvent extracion. Chemical reaction that proposed in scheme 1. To confirm the effectiveness of this derivative material as a chelating agents, we also presented the chelating process that reacted with several metal ions: $\mathrm{Cu}(\mathrm{II}), \mathrm{Co}(\mathrm{II}), \mathrm{Cr}(\mathrm{III})$ and Ni (II). To support the present study, the structure of ligand was characterized using FTIR, $\mathrm{UV},{ }^{1} \mathrm{H}-\mathrm{NMR},{ }^{13} \mathrm{C}-\mathrm{NMR}, \mathrm{MS}$, and elemental analysis. The efficiency of the extractions was evaluated by determining the amount of extracted metals by using Atomic Absorption Spectroscopy.

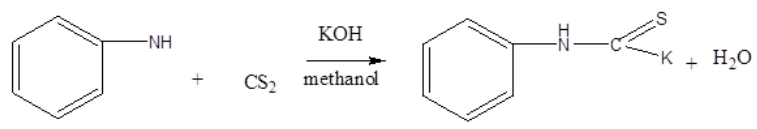

Picture 1. Proposed reaction of synthesis Nphenylaminedithicarbamate

\section{EXPERIMENTAL}

Materials and reagents

$\mathrm{N}$-phenylamine and potassium hydroxide were obtained from Merck while carbon disulphide was from Sigma-Aldrich, All chemical including of $\mathrm{Co}\left(\mathrm{NO}_{3}\right) \cdot 6 \mathrm{H}_{2} \mathrm{O}, \mathrm{Cu}\left(\mathrm{NO}_{3}\right)_{2} \cdot 3 \mathrm{H}_{2} \mathrm{O}, \mathrm{NiCl}_{2} \cdot 6 \mathrm{H}_{2} \mathrm{O}$, and $\mathrm{CrCl}_{3} .6 \mathrm{H}_{2} \mathrm{O}$ were used of analytical reagent or higher purity grade. Solvent was used without further purification.

\section{Physical Instruments}

Electronic absorption spectra were recorded with a UV-Vis Mini Shimadzu 1240 Spectroscopy. Infrared spectra were recorded with a Shimadzu FTIR 8400 spectrophotometer in the range of 4000-400 $\mathrm{cm}-1$ in $\mathrm{KBr}$ pellets. Elemental analysis of carbon, hydrogen, nitrogen carried out on an elemental analyzer. $\quad{ }^{1} \mathrm{H}$ and ${ }^{13} \mathrm{C}$ NMR spectral recorded on an Advance DRX 400 spectrometer at $400 \mathrm{MHz}$ using tetramethylsilane as internal reference in. 


\section{Synthesis of ligands}

$\mathrm{N}$-phenylaminedithiocarbamate was synthesized by a modification of the procedure described (Pitchaimani et al., 2013). The procedure consisted of adding carbon disulfide $(0,05 \mathrm{~mol})$ into an ice-cold mixture of $\mathrm{N}$-phenylamine $(0.05 \mathrm{~mol})$ and $15 \mathrm{~mL}$ of concentrated potassium hydroxide in methanol with vigorous stirring for 5 hours. The mixture was stirred at room temperatur until solid yellowsh-white preciptate resulted and filtered. The product was washed three times with cold methanol, and then dried in vacum. Elemental analysis, found : C, 38.83 ; H, 3.29 ; N, 5.89\%, calculated : C, 40,56 ; H, 2.90 ; $\mathrm{N}, 6.76 \%$.

\section{Application of $\mathrm{N}$-phenylaminedithiocarbamate in solvent extraction}

Solvent extraction was carried out by adding 1 $\mathrm{mL}$ solution ligand $1 \%$ to $10 \mathrm{~mL}$ aqoues metal salt $100 \mathrm{ppm}$ and buffer solution in separating funnel shaked vigourously. Mixture was separated to determine quantitative residu of metal by AAS.

\section{RESULT AND DISSCUSSION}

Elemental analysis reveals that the ligand rather not good purity. It appered in melting point is at range $148-152{ }^{\circ} \mathrm{C}$. Based on the analysis of UV spectroscopy, N-phenyldithiocarbamate has a wavelength maximum at $284.5 \mathrm{~nm}$ showed a high absorbance intensity caused two NCS2 chromophore bands due to transitions of electrons by $\pi-\pi *$ for a wavelength of $300 \mathrm{~nm}$ and $\mathrm{n}-\pi *$ transition $200-700$ $\mathrm{nm}, \mathrm{e}=10-100$ ) for wavelengths 272 , but after being tested with UV-VIS Spectrophotometer which appears to ligand anilinditiocarbamate at a wavelength of about $273 \mathrm{~nm}$ due to the transition of electrons $\pi-\pi$ * and $n-\pi$ electron transition * for the wavelength 204.0 $\mathrm{nm}$, whereas $300 \mathrm{~nm}$ does not exist.

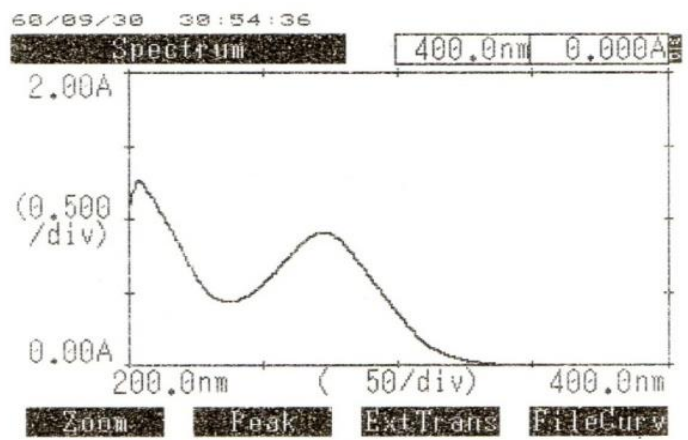

Picture 2. UV Spectrum of Anilinditiocarbamate

Based on the results of FT-IR for anilinditiocarbamate ligand, which produced some of the sharp peak at $1450,4 \mathrm{~cm}^{-1}$ for the $\mathrm{C}=\mathrm{N}$ anilinditiocarbamate ligand and the resulting aniline bond $\mathrm{C}=\mathrm{N}$ at wave number $1467,7 \mathrm{~cm}^{-1}$. As for the $\mathrm{C}$ $=\mathrm{S}$ ranges from $1002,9 \mathrm{~cm}^{-1}$ and $1070.4 \mathrm{~cm}^{-1}$ in the anilinditiocarbamate, while the resulting aniline bond at wavenumber $995,2 \mathrm{~cm}^{-1}$ and $1026,1 \mathrm{~cm}^{-1}$.

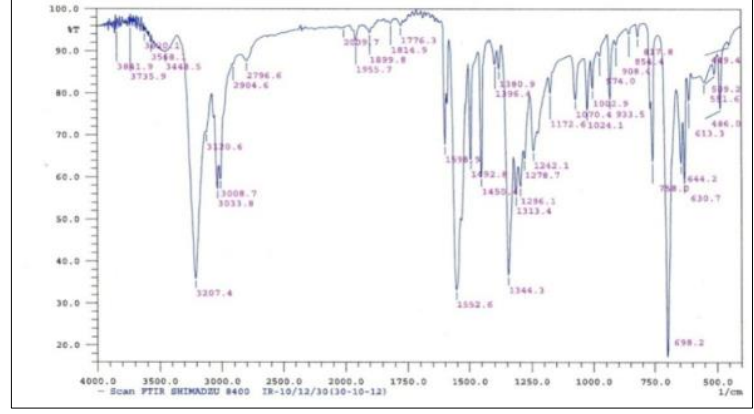

Picture 3. FTIR Spectrum of Anilindithiocarbamate

Stretching at the $\mathrm{C}=\mathrm{S}$ can show anilinditiocarbamate ligand is monodentate or bidentate. According to the theory that Bonati and Ugo monodentate bonding will occur when there are two peaks at wave number $1000 \mathrm{~cm}^{-1}$ are separated by the wavelength of the extent of more than $20 \mathrm{~cm}^{-1}$ due to the two $\mathrm{C}=\mathrm{S}$ stretching bonds are not equivalent and asymmetric. As for bonding bidentate ligand anilinditiocarbamate will appear one peak at wave number $1000 \mathrm{~cm}^{-1}$ which indicates that symmetric ties. Based on the results of research conducted that has two anilinditiocarbamate ligand bond stretching the $\mathrm{C}=\mathrm{S}$, so it can be concluded that the ligand is monodentate and bond anilinditiocarbamate asymmetric. In figure 6 shows that if the bond is a monodentate ligand anilinditiocarbamate or bidentate.<smiles>[R16]C1S[N+]2(S1)SC([Y16])S2</smiles>

Bidentate symmetrical bonding<smiles>[R16]C(=S)SN=S(N)[Na]</smiles>

Monodentate unsymmetrical bonding
Picture 4. Monodentat Structure of dithiocarbamate

\section{Application anilin dithiocarbamate in Solvent Exctracion}

Table 1. Percent extraction (\%E) of $\mathrm{Cu}(\mathrm{II}), \mathrm{Co}$ (II), $\mathrm{Cr}(\mathrm{III})$ dan Ni (II)

\begin{tabular}{ccccc}
\hline \multirow{2}{*}{$\mathrm{pH}$} & \multicolumn{4}{c}{$\% \mathrm{E}$} \\
& $\mathrm{Cu}(\mathrm{II})$ & $\mathrm{Co}(\mathrm{II})$ & $\mathrm{Cr}(\mathrm{III})$ & $\mathrm{Ni}(\mathrm{II})$ \\
\hline 4 & 99,00 & 92,26 & 93,40 & 90,76 \\
5 & 99,78 & 92,65 & 93,33 & 91,04 \\
6 & 99,98 & 92,36 & 92,06 & 90,45 \\
7 & 99,94 & 94,15 & 93,35 & 92,91 \\
8 & 99,96 & 94,02 & 93,46 & 92,69 \\
9 & 99,99 & 92,47 & 94,96 & 90,73 \\
\hline
\end{tabular}

\section{CONCLUSION}

The melting point of anilin dithiocarbamate has range $148-152{ }^{\circ} \mathrm{C}$ and crystalite. At the $\mathrm{pH}$ range $4-9$ percent ectraction (\%) 90,73 to 99,99 .

\section{REFERENCES}

Cao, M. Wei, Z. Chen*, and B. Y. Huang. 2013. Analyst 138, 2420. 
Crnogorac,G. and Schwack, W. 2009. Residue analysis of dithiocarbamate fungicides, $\operatorname{TrAc}$ Trends in Analytical Chem. 28:40-50.

Dilli, S., and P. Thong, 1999. Analitica Chimica Acta 395. 101-112.

Lehotay, J. O., Liskă, Bardšteterovă, and G. Guiochon, 1979. Journal. of Chromatography 172:379-383.

Liskă, O., G. Guiochon, and H. Colin. 1979. Journal of Chromatography, 171:145-151.

Manav, A.K. Mishra, N.K. Kaushik. 2004. Spectrochimica Acta Part A 60:3087-3092.
Manav, A.K. Mishra, and N. K. Kaushik. 2006. Spectrochimica Acta Part A 65:32-35.

Onwudiwe, C. A. Strydom, and O.S. Oluwafemi. 2013. New J . Chem., 37:834-842.

Pitchaimani, et al, 2013. Series of lanthanide(III) azepane dithiocarbamate complexes, Polyhedron 54:60-66.

Shi, W. Chu, Y. Wang, S. Wang, J. Du, J. Zhang,S. Li, G. Zhou, X. Qin, C. Zhang. 2013. Inorganic Chemistry Comm. 30:178-181.

Wang, S.F. and Wai,C.M. 1999. Journal of chromatography Sci.32(11) 506-510. 